\title{
Iron-Modification of Pyroclastic Material from PCCVC Eruption (Chile): Characterization and Application to Remove Arsenic from Groundwater
}

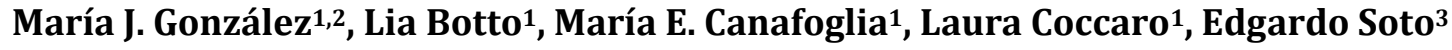 \\ ${ }^{1}$ CEQUINOR (CCT-La Plata-CONICET-UNLP), La Plata, Argentina \\ ${ }^{2}$ INREMI (CICPBA-UNLP), La Plata, Argentina \\ ${ }^{3}$ CINDECA (CCT-La Plata-CONICET-UNLP), La Plata, Argentina \\ Email: botto@quimica.unlp.edu.ar
}

Received 19 August 2015; accepted 11 October 2015; published 14 October 2015

Copyright (C) 2015 by authors and Scientific Research Publishing Inc.

This work is licensed under the Creative Commons Attribution International License (CC BY).

http://creativecommons.org/licenses/by/4.0/

c) (i) 0pen Access

\begin{abstract}
Pyroclastic material from the PCCVC eruption (Chile) was modified with iron (III) solutions leading to the formation of ferrihydrite surface deposits. The aim of the chemical treatment was to prepare an adsorbent to remove arsenic from water by using low-cost mineral wastes. Physicochemical characterization of original and modified materials was carried out by XRD, BET-N $\mathrm{N}_{2}$ adsorption, SEM-EDS microscopy and ICP-AES chemical analysis. The modified ash revealed that the increase of bulk iron content was close to $5 \%$ (expressed as $\mathrm{Fe}_{2} \mathrm{O}_{3}$ ) whereas surface values were $20.6 \% \mathrm{Fe}_{2} \mathrm{O}_{3}$. Surface properties showed an increase of BET specific surface with prevalence of mesopores and an increase of total pore volume attributed to presence of nanoscopic iron phase. Kinetic and equilibrium studies were directed to optimize the operative conditions related to the material adsorptive capacity for removing arsenate species. Hence, the adsorbent dose, contact time, $\mathrm{pH}$, stirring and sedimentation were evaluated in batch process. The optimal adsorption dose was $40 \mathrm{~g} \cdot \mathrm{L}^{-1}$ and the solid-liquid contact time was stirring $(1 \mathrm{~h})$ and sedimentation $(23 \mathrm{~h})$, enough to ensure an adequate turbidity value valid for a $\mathrm{pH}$ range between 3.77 and 8.95 . The analysis of the isotherm equilibrium by using the Langmuir linear method showed a $R^{2}=0.995$ value. The performance of the treatment to remove arsenic by using a cost-effective adsorbent prepared from volcanic material is a promising technology to apply in the environmental field.
\end{abstract}

\section{Keywords}

Volcanic Ash, Iron Modification, Arsenic Removal, Groundwater 


\section{Introduction}

Arsenic is a very toxic element which as $\mathrm{AsO}_{3}^{3-}$ and $\mathrm{AsO}_{4}^{3-}$ oxyanion species is found in groundwater of some regions affected by past volcanic events [1] [2]. Due to high public health risks, the World Health Organization established for drinking water the limit of $10 \mu \mathrm{g}$ As per liter [3]. Argentina is one of the most affected countries of South-America, where the contamination has become a serious social and health problem [1] [2] [4]. Other affected countries, such as those located in Asia (Bangladesh, China, India), show chronic health diseases associated to As presence in water [1] [5]-[7]. The problem is particularly observed in rural zones without any other water sources for human consumption. Several techniques are employed to remediate the trouble but the adsorption procedure, based on the use of metal-oxide systems as adsorbents, seems to be an efficient technology, showing advantages respect to other ones (reverse osmosis and ion exchange for example) due to low cost, easy implementation, as well as operational simplicity [8]-[11]. A large number of natural and synthetic systems are investigated due to the urgent need to find solutions. Iron oxy-hydroxides as goethite, hematite, red mud as well as zeolites and clay minerals (as natural iron-rich phases or chemically modified) are used as adsorbents with different results [8] [10]-[12]. On the basis of affinity between the arsenate oxyanion with metallic sites (particularly $\mathrm{Al}$ and $\mathrm{Fe}$ ), all of them are adequate in different proportion to remove arsenic [13]-[15]. Arsenate (V) is the inorganic form in which the arsenic appears in Argentinean groundwater resources [1] [2] [16].

The use of iron-impregnated volcanic ash is reported as methodological alternative for arsenic removal [17] [18]. In this context, the eruption of Puyehue Cordon Caulle Volcanic Complex (Chile), on June 2011, left a large amount of volcanic ash on argentine territory [19]. Preliminary studies about the mineralogy and properties of the pyroclastic mixture reveal the presence of glassy material with scarce proportion of crystalline phases (iron oxides, pyroxene and plagioclase mineral species) [20]-[22].

Considering that the accumulation of pyroclastic material is risky for health and environment, and taking into account the imperative need to provide safe drinking water in the south of "Chaco-Pampeana" region, this paper reports the results of a simple chemical modification of volcanic waste and its potentiality as adsorbent to remove arsenic in groundwater. Physicochemical techniques such as inductively coupled plasma atomic emission spectrometry (ICP-AES), X-ray Diffraction (XRD), scanning electron microscopy with electron diffraction spectroscopy (SEM-EDS) and BET specific surface are used to know about the properties and behavior of the adsorbent system. The operational parameters of the adsorption process (iron content, adsorbent dose, solid-water contact time, initial $\mathrm{pH}$, sedimentation conditions) were optimized and the quality of the resulting water was monitored by arsenic, $\mathrm{pH}$ and turbidity measurements.

\section{Materials and Methods}

\subsection{Materials}

The volcanic material (VM) was collected from natural accumulations in Villa La Angostura, Argentina $\left(40^{\circ} 45^{\prime} 48^{\prime \prime} \mathrm{S}, 71^{\circ} 38^{\prime} 46^{\prime \prime} \mathrm{W}\right)$, five months after the eruption. In this area, the depth of accumulated pyroclasts was close to $30 \mathrm{~cm}$. Bulk samples were dried $\left(60^{\circ} \mathrm{C}\right)$ and sieved (American Society for Testing and Materials mesh) to obtain fractions of particle size between $0.105-1.680 \mathrm{~mm}$.

Adsorption experiments were done with water prepared from a standard $\mathrm{As}(\mathrm{V})$ solution containing $1 \mathrm{~g}$ of As $\mathrm{L}^{-1}$ which was obtained by dissolving sodium hydrogen arsenate $\left(\mathrm{Na}_{2} \mathrm{HAsO}_{4} \cdot 7 \mathrm{H}_{2} \mathrm{O}\right.$, Mallinckrodt $)$ in distilled water. Water samples with minor arsenic concentration were obtained from the standard solution by dilution with tap water in order to ensure the mineralization of real water. In this sense, different results, attributed to the ionic strength of natural mineralization, are reported for the use of natural or deionized water [17]. Chemical composition of the tap water is given in Table 1 .

The chemical activation of VM was carried out at room temperature by treatment with Fe(III) salts, following the technique described by Schwertmann and Cornell [23] to get ferrihydrite. The method consists in the combination of ash with solutions of $\mathrm{FeCl}_{3} \cdot 6 \mathrm{H}_{2} \mathrm{O}$ and $\mathrm{KOH}$ (conc. 1M). For each $100 \mathrm{~g}$ of VM, it was used $20 \mathrm{~g}$ of $\mathrm{FeCl}_{3} \cdot 6 \mathrm{H}_{2} \mathrm{O}$ dissolved in $250 \mathrm{~mL}$ water and $155 \mathrm{~mL} \mathrm{KOH}$ to maintain $\mathrm{Fe}^{+3} / \mathrm{OH}^{-}=1 / 3$ ratio. $\mathrm{KOH}$ was added to adjust the $\mathrm{pH}$ to neutrality. The modified sample called Fe-VM was washed until complete removal of chloride, centrifuged and then oven dried at $60^{\circ} \mathrm{C}$. With comparative purposes, pure ferrihydrite was synthesized using the same technique. 
Table 1. Chemical composition of the tap water employed in the preparation of arsenic solutions.

\begin{tabular}{ccc}
\hline Parameter & Result \\
\hline $\mathrm{pH}$ & 7.75 \\
Conductivity $\left(\mu \mathrm{mhos} \mathrm{cm}^{-1}\right)$ & 637 \\
Turbidity $(\mathrm{NTU})$ & $<3$ \\
Calcium $\left(\mathrm{mg} \cdot \mathrm{L}^{-1}\right)$ & 35 \\
Magnesium $\left(\mathrm{mg} \cdot \mathrm{L}^{-1}\right)$ & 18 \\
Sodium $\left(\mathrm{mg} \cdot \mathrm{L}^{-1}\right)$ & 145 \\
Potassium $\left(\mathrm{mg} \cdot \mathrm{L}^{-1}\right)$ & 8 \\
Bicarbonate $\left(\mathrm{mg} \cdot \mathrm{L}^{-1}\right)$ & 121 \\
Chloride $\left(\mathrm{mg} \cdot \mathrm{L}^{-1}\right)$ & 150 \\
Sulfate $\left(\mathrm{mg} \cdot \mathrm{L}^{-1}\right)$ & 80 \\
Nitrate $\left(\mathrm{mg} \cdot \mathrm{L}^{-1}\right)$ & 7.8 \\
Fluoride $\left(\mathrm{mg} \cdot \mathrm{L}^{-1}\right)$ & 0.18 \\
Arsenic $\left(\mathrm{mg} \cdot \mathrm{L}^{-1}\right)$ & $<0.01$ \\
\hline
\end{tabular}

\subsection{Analysis and Methods}

The VM and Fe-VM chemical analyses were performed by ICP-AES technique for major elements. The ICPMS analysis was employed for arsenic element (ALS Chemex Lab, Canada). X-ray Diffraction patterns were collected with a PHILIPS PW 1710 diffractometer using $\mathrm{Cu}$ K $\alpha$ Ni-filtered radiation. SEM-EDS measurements were performed in an ESEM (FEI Quanta 200), with tungsten filament and ETD (high vacuum secondary electron) detector. Microanalysis was carried out with an EDAX Detector Apollo 40. Chemical results were expressed as \%w/w oxides. The BET surface area was measured by $\mathrm{N}_{2}$ adsorption using a Micromeritics ASAP 2020 automated Braunauer-Emmet-Teller Sorptometer. Samples were degassed for $10 \mathrm{~h}(\mathrm{P}<10 \mu \mathrm{m}$ of $\mathrm{Hg}$, temperature $\left.100^{\circ} \mathrm{C}\right)$. The specific surface $(\mathrm{BET})$ was obtained from the $\mathrm{N}_{2}$ adsorption isotherm $\left(\mathrm{P} / \mathrm{P}_{0}\right.$ between $0.01-0.3$ ) whereas the pore size distribution done by the DFT (Density Functional Theory) method was obtained in the pressure $\mathrm{P} / \mathrm{P}_{0} 0.01$ - 0.99 range.

The As concentration in aqueous solutions was analyzed by means of an atomic absorption spectrometer (GF-AAS Perkin Elmer Analyst 200) equipped with a Perkin Elmer HGA 900 graphite-furnace. Turbidity was determined by using a turbidimeter Hanna HI 93703 whereas the pHmeter Denver Instrument Ultrabasic Benchtop was used to measure the water $\mathrm{pH}$.

\subsection{Batch Experiments}

Batch experiments were carried out at room temperature $\left(20^{\circ} \mathrm{C} \pm 2^{\circ} \mathrm{C}\right)$ in jar test equipment (Velp Scientifica JLT6). The experiments were performed in duplicate and the mean values were considered (results show a variation of $\pm 3 \%$ ). Assays were performed to evaluate the effect of contact time with shaking at $150 \mathrm{rpm}$ as well as the sedimentation time, the dose of adsorbent and the $\mathrm{pH}$.

In order to find out the optimal contact time, experiments were carried out using an initial concentration $\mathrm{As}(\mathrm{V})$ of $0.500 \mathrm{mg} \cdot \mathrm{L}^{-1}$ and a solid/liquid ratio $1 / 100$ (7.5 g of adsorbent and $750 \mathrm{ml}$ of solution). The $\mathrm{pH}$ was maintained at $\mathrm{pH}$ 7.75. The time was varied between 30 and 240 minutes using an agitation of $150 \mathrm{rpm}$. The turbidity and the solution $\mathrm{pH}$ were controlled. An aliquot of the solution was filtered through a $0.45 \mu \mathrm{m}$ nylon filter and the filtrate was used for analysis of remaining arsenic concentration.

To determine the optimal adsorbent dose, experiments were carried out using adsorbent doses between 5-100 g adsorbent $\mathrm{L}^{-1}$. The arsenic concentration was $0.500 \mathrm{mg} \cdot \mathrm{L}^{-1}$, the solution $\mathrm{pH} 7.75$ and the contact time $60 \mathrm{mi}-$ nutes at $150 \mathrm{rpm}$. After stirring, turbidity, $\mathrm{pH}$ and As concentration were measured in a procedure similar to that mentioned above. 
Additionally, taking into account the turbidity reference value of $\leq 3$ NTU and results obtained in previous works [12], the stirring process for 60 min was supplemented by a $23 \mathrm{~h}$ settling period, so completing a total contact time of 24 hours ( $1 \mathrm{~h}$ at $150 \mathrm{rpm}$ and 23 hours at rest). After this time, the same determinations were performed.

Studies were also conducted to find out the optimum $\mathrm{pH}$ range. The $\mathrm{pH}$ effect was evaluated in the range from 3.77 to 8.95 . The $\mathrm{pH}$ of solutions was adjusted by adding $0.1 \mathrm{M}$ solutions of $\mathrm{HCl}$ or $\mathrm{NaOH}$. Assays were performed at an initial $\mathrm{As}(\mathrm{V})$ concentration of $0.500 \mathrm{mg} \cdot \mathrm{L}^{-1}$ for a stirring period of 60 minutes at $150 \mathrm{rpm}$ and 23 sedimentation hours with an adsorbent dose of $40 \mathrm{~g} \cdot \mathrm{L}^{-1}$, according to previous results. Turbidity, $\mathrm{pH}$ and As concentration were determined.

In all experiments, the concentration of arsenic adsorbed on the solid was calculated by subtracting the final measured concentration $\left(C_{e}\right)$ to the initial concentration of arsenic introduced in the solution $\left(C_{0}\right)$. Results are given in percentage of arsenic removed (\%Re):

$$
\frac{\% \operatorname{Re}=\left(C_{0}-C_{e}\right) \times 100}{C_{0}}
$$

Langmuir isotherms were conducted in order to investigate the maximum adsorption capacity Fe-VM taking into account the behavior of the unmodified material. Operating conditions optimized in the above items were used. Arsenic concentrations between 0.450 and $18.3 \mathrm{mg} \cdot \mathrm{L}^{-1}$ were employed.

\section{Results and Discussion}

\subsection{Physicochemical Characterization of Samples}

Table 2 presents the ICP-AES chemical data for VM and Fe-VM. The iron content increase was slightly lesser than $5 \%$ (expressed as \%w/w of $\mathrm{Fe}_{2} \mathrm{O}_{3}$ ), while the $\mathrm{SiO}_{2} / \mathrm{Al}_{2} \mathrm{O}_{3}$ ratio was comparable in both cases $(4.4$ and 4.5 for $\mathrm{VM}$ and Fe-VM respectively). These results can be correlated with some others obtained for natural species including aluminosilicates and volcanic ash [12] [17]. The low specific surface of these minerals $\left(\mathrm{S}_{\mathrm{BET}}<12\right.$ $\mathrm{m}^{2} \cdot \mathrm{g}^{-1}$ ) limits the magnitude of the surface deposit of iron phase caused by the fast alkaline hydrolysis of $\mathrm{Fe}(\mathrm{III})$ salts.

Likewise, the As content in the original sample, measured by the ICP-MS technique, was $12.4 \mathrm{ppm}$. This value can be correlated with the original iron content, as it is observed in other aluminosilicates already studied (richer and poorer in iron) [12].

On the other hand, the selected pyroclastic fraction was predominantly amorphous to X-ray corroborating that vitreous particles prevail respect to crystaloclastic and lithoclastic phases. XRD-patterns of iron activated samples did not present differences with those of natural samples. This fact could be attributed to the small amount of added iron phase and/or to its low crystallinity. Similar behavior is also observed in the activation of other aluminosilicates [12] [24]. Ferrihydrite is structurally poorly crystalline [25]. The two forms, named two and six line ferrihydrite, show a reduced number of XR signals, being the most intense at $\sim 22^{\circ}$ of $2 \theta$ [26]. Although the stability of two-line ferrihydrite is increased in certain conditions, preventing its transformation to crystalline Fe-oxide phases, hematite is the resulting alteration product, observed in nature or in laboratory. The transformation depends particularly on temperature and time [24] [26].

SEM results for VM and Fe-VM are shown in Figure $1 \mathrm{a}$ and $\mathrm{b}$ respectively. The typical vesicular morphology of the VM material was replaced by covered particles resulting from the deposition of iron phase on the surface and vesicles of Fe-VM material. EDS chemical data for original and activated materials is given in Table 3. The comparison between the bulk and surface results for VM and Fe-VM reveals the marked increase on the surface iron content after the iron activation, whereas $\mathrm{SiO}_{2} / \mathrm{Al}_{2} \mathrm{O}_{3}$ ratios remain comparable. These values

Table 2. ICP-AES major and minor elements (expressed as \% oxides).

\begin{tabular}{cccccccccccc}
\hline$\%$ & $\mathrm{SiO}_{2}$ & $\mathrm{Al}_{2} \mathrm{O}_{3}$ & $\mathrm{Fe}_{2} \mathrm{O}_{3}$ & $\mathrm{CaO}$ & $\mathrm{MgO}$ & $\mathrm{Na}_{2} \mathrm{O}$ & $\mathrm{K}_{2} \mathrm{O}$ & $\mathrm{TiO}_{2}$ & $\mathrm{MnO}$ & $\mathrm{P}_{2} \mathrm{O}_{5}$ & $\mathrm{LOI}$ \\
\hline $\mathrm{VM}$ & 65.9 & 14.43 & 6.98 & 3.14 & 1.13 & 4.99 & 2.28 & 0.80 & 0.15 & 0.16 & 0.04 \\
$\mathrm{Fe}-\mathrm{VM}$ & 62.0 & 13.95 & 11.68 & 3.07 & 1.00 & 4.38 & 2.41 & 0.73 & 0.14 & 0.15 & 0.49 \\
\hline
\end{tabular}

LOI: weight loss on ignition at $1000^{\circ} \mathrm{C}$. 
Table 3. EDS chemical analisys of original and modified samples.

\begin{tabular}{cccccccccc}
\hline$\%$ & $\mathrm{Na}_{2} \mathrm{O}$ & $\mathrm{MgO}$ & $\mathrm{Al}_{2} \mathrm{O}_{3}$ & $\mathrm{SiO}_{2}$ & $\mathrm{~K}_{2} \mathrm{O}$ & $\mathrm{CaO}$ & $\mathrm{TiO}_{2}$ & $\mathrm{Fe}_{2} \mathrm{O}_{3}$ \\
\hline $\mathrm{VM}$ & 5.6 & 0.6 & 15.4 & 67.6 & 1.2 & 2.0 & 0.7 & 6.9 \\
$\mathrm{Fe}-\mathrm{VM}$ & 5.1 & 0.4 & 12.9 & 56.4 & 2.9 & 1.5 & 0.2 & 20.6 \\
\hline
\end{tabular}
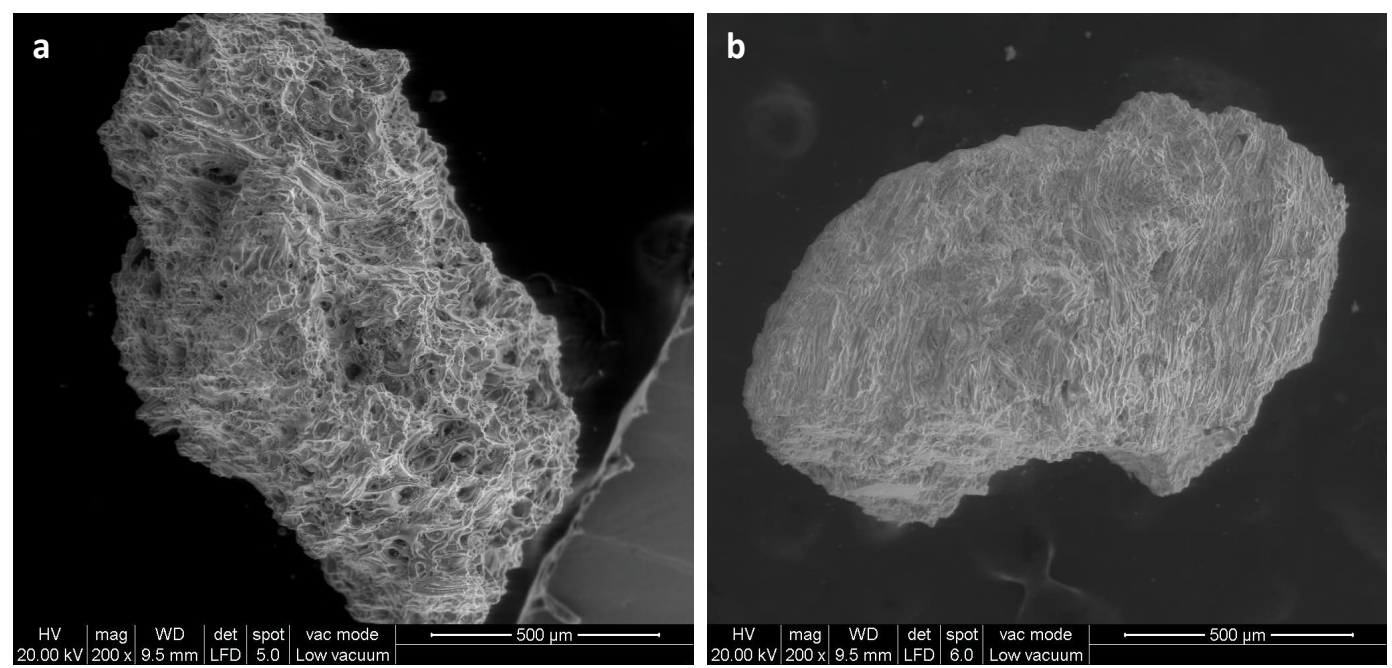

Figure 1. SEM micrographs of VM (a) and Fe-VM (b).

clearly show the effect of hydrated oxy-hydroxide iron phase deposition.

Data of specific surface by BET method follow the sequence VM $<$ Fe-VM $<$ ferrihydrite $(0.76<4.94<$ $\left.322.44 \mathrm{~m}^{2} \cdot \mathrm{g}^{-1}\right)$. Figure 2 shows comparatively the pore size distribution for the three materials according to DFT method. Whereas the ferrihydrite used as reference presented prevalence of mesopores (average pore width $28.47 \AA$ ), VM material presented a wide distribution of meso and macropores (average pore width 107.29). FeVM activated sample showed an intermediate behavior, with an increase of mesopores and a pronounced decrease of macropores. This aspect was correlated to the higher specific surface by effect of iron-nanophase deposition, covering the original macro and mesopores. Likewise, the total pore volume was considerably increased (from 0.00178 to $0.00317 \mathrm{~cm}^{3} \cdot \mathrm{g}^{-1}$ ).

\subsection{Potentiality of the Modified Material for Arsenic Removal: Evaluation from Batch Experiments}

\subsubsection{Effect of the Adsorbent/Water Contact Time}

The optimization of the contact time, according to experimental procedure indicated in item 2 was obtained from the plot of As removed (\%Re) vs. adsorption time (min), as shown in Figure 3. The adsorption equilibrium was practically reached starting from $60 \mathrm{~min}$, in a behavior similar to that reported by [27] using natural species as adsorbents. However, the turbidity was higher than 3 NTU, value that can be associated to the nanoscopic nature of the iron phase deposited on the volcanic material.

\subsubsection{Adsorbent Dose and Sedimentation Time Effects}

Figure 4 shows the As removal (\%Re) vs. adsorbent dose, according to the two treatments detailed in experimental conditions: a) $1 \mathrm{~h}$ at $150 \mathrm{rpm}$ (without sedimentation) and b) $1 \mathrm{~h}$ at $150 \mathrm{rpm}$ plus a sedimentation period of $23 \mathrm{~h}$. Optimum dose for the first case was $70 \mathrm{~g} \cdot \mathrm{L}^{-1}$ whereas a lower dose of $40 \mathrm{~g} \cdot \mathrm{L}^{-1}$ was obtained for the second case. In both conditions the \%Re was close to $98 \%$.

The turbidity values vs. adsorbent dose given in Figure 5 reveal that the stirring process without sedimentation was not enough to reach turbidity values required by a drinking water. The sedimentation period of 23 hours was sufficient to assure the water quality. 


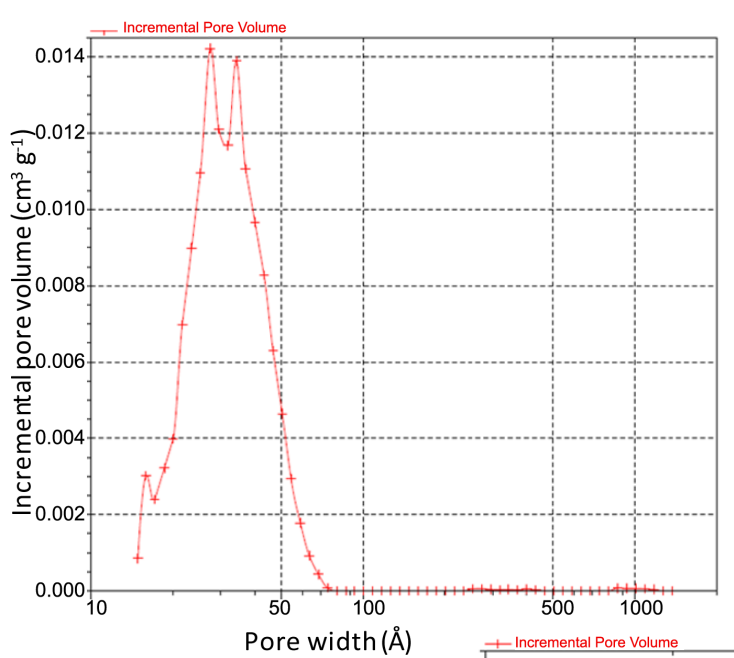

(a)

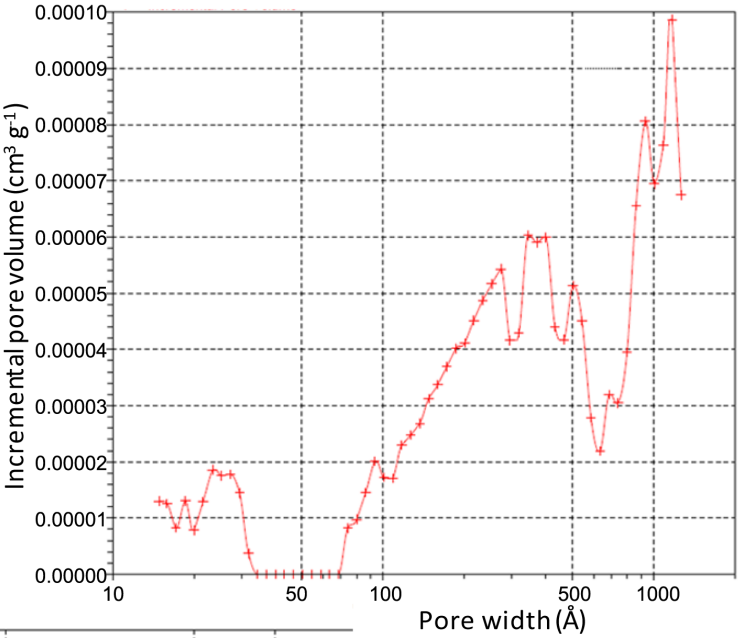

(b)

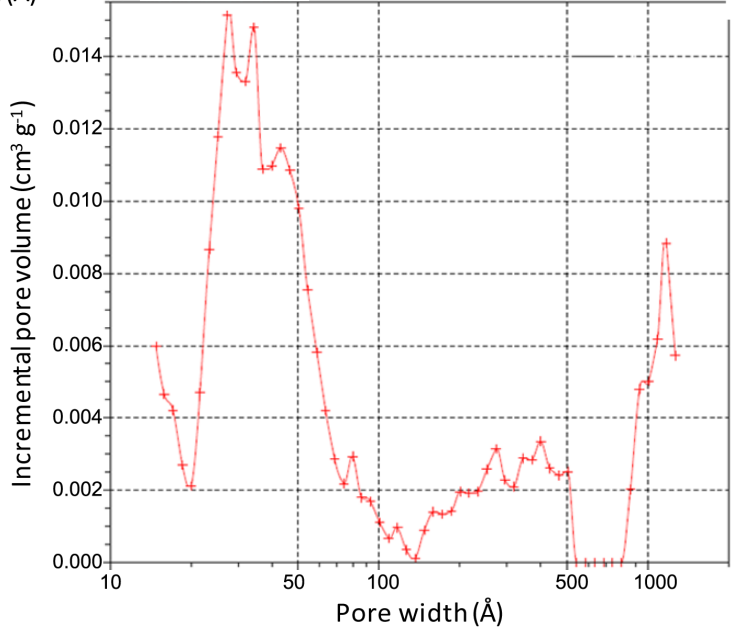

(c)

Figure 2. Density functional theory applied to the (a) Ferrihydrite; (b) VM and (c) Fe-VM.

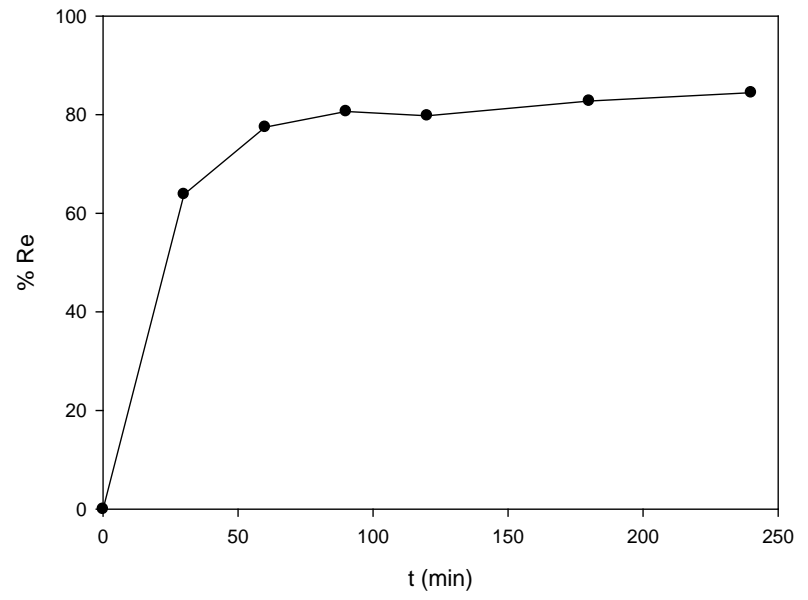

Figure 3. As removed (\%Re) vs. adsorption time (initial As $0.500 \mathrm{mg} \cdot \mathrm{L}^{-1}, \mathrm{pH} 7.75$, adsorbent dose $\left.10 \mathrm{~g} \cdot \mathrm{L}^{-1}, 150 \mathrm{rpm}\right)$.

\subsubsection{The $\mathrm{pH}$ Effect}

The pH effect was analyzed by using values between 3.77 and 8.95 . According to the procedure detailed in the 


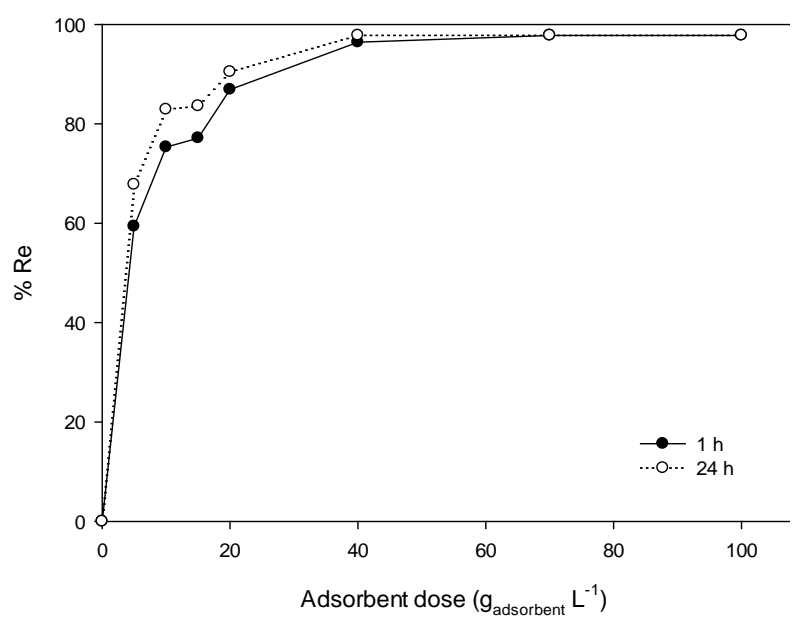

Figure 4. As removed vs. dose of Fe-VM for the two studied treatments (initial As $0.500 \mathrm{mg} \cdot \mathrm{L}^{-1}, \mathrm{pH} 7.75$ ).

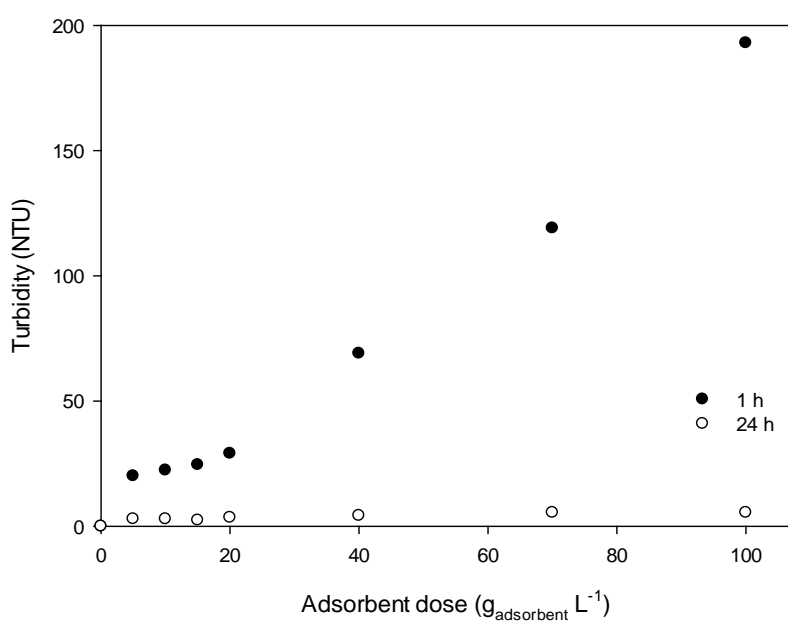

Figure 5. Turbidity vs. dose of Fe-VM for the two studied treatments (initial As $0.500 \mathrm{mg} \cdot \mathrm{L}^{-1}$, $\mathrm{pH} 7.75$ ).

experimental item and starting from As solutions of $0.500 \mathrm{mg} \cdot \mathrm{L}^{-1}$, values after treatment were in all $\mathrm{pHs}$ lower

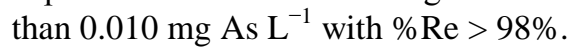

It is well known that arsenate adsorption onto iron oxy-hydroxides is favored when the surface charge of the solid is positive. For these species the surface charge occurs by direct proton transfer and the adsorption is enhanced when the solution $\mathrm{pH}$ is lower than the PZC value of the solid (ranged between 6.5 - 8.7) [11] [27] [28]. On the other hand, it is interesting to indicate that the pHs after treatment were in the range 6.85 and 7.92, in agreement with that reported by Guo et al. [27], by using natural adsorbents. From these results it is evident that the water not requires additional treatment to reach the $\mathrm{pH}$ values corresponding to the drinking water standard of Argentina (pH: 6.5 - 8.5). Likewise, the water turbidity in all cases was lower than 3 NTU in the used experimental conditions, no revealing undesirable solutes. It is known that, other good arsenic adsorbents can modify some parameters of the water quality such as $\mathrm{pH}$ and turbidity [29].

\subsubsection{Isotherm Study}

As the adsorption process of arsenic removing from natural species (hematite, goethite, red mud, and other iron oxide materials) as well as ferric impregnated minerals, follow the Langmuir isotherm [17] [27]-[29]. In this work, the Langmuir plot for water samples containing As concentrations between 0.450 to $18.3 \mathrm{mg} \cdot \mathrm{L}^{-1}$ led to linearized form of Figure 6, according to equation: 


$$
C_{e} / q_{e}=1 / b q_{\max }+C_{e} / q_{\max }
$$

where $q_{e}\left(\mathrm{mg}^{-1}\right)$ is the amount of solute adsorbed at equilibrium and $C_{e}\left(\mathrm{mg} \cdot \mathrm{L}^{-1}\right)$ is the equilibrium concentration. Constants b and $q_{\max }$ were calculated from the slope and the intercept of plot between $C_{e} / q_{e}$ and $C_{e}$. The good fit of the Langmuir isotherm obtained for the activated Fe-VM sample suggested that the coverage of adsorption sites was in the form of a monolayer and that all surface sites had nearly the same adsorption energy as it is observed in other natural and impregnated systems [17] [27] [29] [30]. Table 4, giving comparatively values of the constants for VM and Fe-VM, revealed the effectiveness of the activated sample.

The adsorption capacity of the samples was dependent on the physicochemical properties of the ash/iron system such as specific surface area and total pore volume generated by the presence of the iron nanoscopic surface phase [12] [29]. In fact, the treatment with iron salts creates active sites for the arsenate (V), interacting through the formation of inner-sphere bidentate or monodentate surface complexes [31].

\section{Conclusions}

Volcanic material from the PCCVC eruption was characterized and chemically modified by treatment with iron (III) solutions. The process led to the formation of a ferrihydrite deposit (specific surface $322 \mathrm{~m}^{2} \cdot \mathrm{g}^{-1}$ ) with an increase of the bulk iron content close to $5 \%$ as $\mathrm{Fe}_{2} \mathrm{O}_{3}$. However, EDS technique revealed an appreciable increase of surface iron $\left(20.6 \%\right.$ as $\left.\mathrm{Fe}_{2} \mathrm{O}_{3}\right)$. The iron activated sample presented an intermediate behavior between surface properties of ferrihydrite and the volcanic material with an increase of mesopores, a pronounced decrease of macropores and an increase of the total pore volume (from 0.00178 to $0.00317 \mathrm{~cm}^{3} \cdot \mathrm{g}^{-1}$ ).

Experiments in batch by using Fe-VM adsorbent revealed a low-cost process for removing arsenic from water. The optimal adsorption dose was $40 \mathrm{~g} \cdot \mathrm{L}^{-1}$ and the solid-liquid contact time was stirring $(1 \mathrm{~h})$ and sedimentation $(23 \mathrm{~h}$ ), enough to ensure an adequate turbidity value valid for a $\mathrm{pH}$ range between 3.77 and 8.95. The Langmuir isotherm model allowed obtaining an adsorption capacity $\left(q_{\max }\right)$ of $0.227 \mathrm{mg}$ As adsorbed by $\mathrm{g}$ of Fe-VM. No change in the $\mathrm{pH}$ of the effluent water can be considered as another treatment advantage.

Concluding, results obtained at laboratory scale reveal that the Fe-VM activated material is an interesting alternative to be used as adsorbent for arsenic removal.

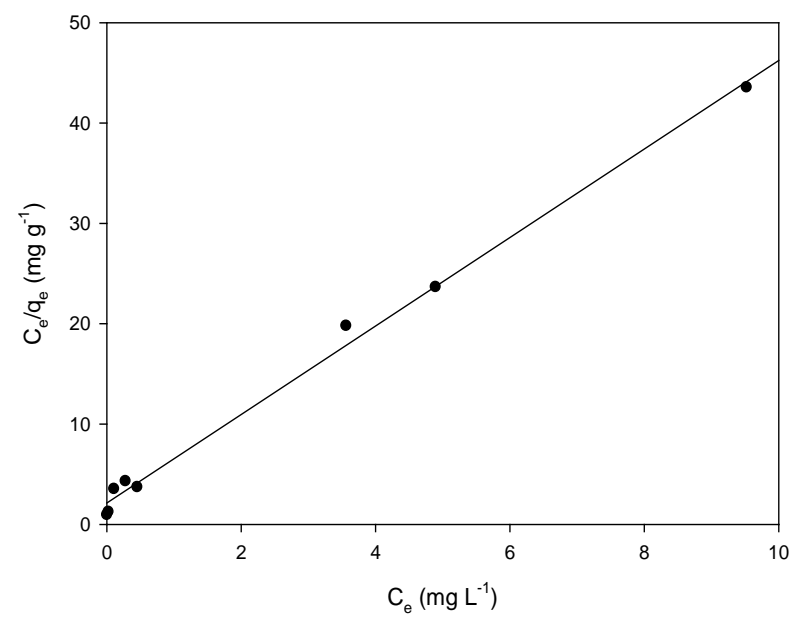

Figure 6. Linearized form of Langmuir isotherm for Fe-MV (adsorbent dose $40 \mathrm{~g} \cdot \mathrm{L}^{-1}, \mathrm{pH} 7.75$, stirring $1 \mathrm{~h}$, sedimentation $23 \mathrm{~h})$.

Table 4. Constants of Langmuir isotherm for VM and Fe-MV.

\begin{tabular}{cccc}
\hline Adsorbent & $q_{\max }\left(\mathrm{mg}_{\mathrm{As}} \mathrm{gad}^{-1}\right)$ & $\mathrm{b}\left(\mathrm{L} \mathrm{mg}_{\mathrm{As}}\right)$ & $\mathrm{R}^{2}$ \\
\hline VM & 0.093 & 0.197 & 0.924 \\
Fe-VM & 0.227 & 2.065 & 0.995 \\
\hline
\end{tabular}




\section{Acknowledgements}

The work was done by financial support of ANPCyT BID 2011 PICT-2186 Argentina.

\section{References}

[1] Smedley, P. and Kinninburgh, D.G. (2002) A Review of the Source, Distribution and Behavior of Arsenic in Natural Waters. Applied Geochemistry, 17, 517-568. http://dx.doi.org/10.1016/S0883-2927(02)00018-5

[2] Bundschuh, J., Litter, M., Parvez, F., Román-Ross, G., Nicolli, H., Jean, J., Liu, J., López, D., Armienta, M., Guilherme, L., Gomez Cuevas, A., Cornejo, L., Cumbal, L. and Toujaguez, R. (2012) One Century of Arsenic Exposure in Latin America: A Review of History and Occurrence from 14 Countries. Science of the Total Environment, 429, 2-35. http://dx.doi.org/10.1016/j.scitotenv.2011.06.024

[3] WHO (2001) Arsenic Compounds, Environmental Health Criteria 224. 2nd Edition, World Health Organization, Geneva.

[4] Nicolli, H., Bundschuh, J., Blanco, M., Tujchneider, O., Panarello, H., Dapeña, C. and Rusansky, J. (2012) Arsenic and Associated Trace-Elements in Groundwater from the Chaco-Pampean Plain, Argentina: Results from 100 Years of Research. Science of the Total Environment, 429, 36-56. http://dx.doi.org/10.1016/j.scitotenv.2012.04.048

[5] Smedley, P. and Kinniburgh, D.G. (2005) Arsenic in Groundwater and the Environment. In: Selinus, O., Ed., Essentials of Medical Geology, Elsevier, Amsterdam, 263-299.

[6] Ravenscroft, P. (2007) The Global Dimensions of Arsenic Pollution of Groundwater. Tropical Agriculture Association, 27, 3-7.

[7] Ravenscroft, P., Brammer, H. and Richards, K.S. (2009) Arsenic Pollution: A Global Synthesis. Wiley-Blackwell, Hoboken. http://dx.doi.org/10.1002/9781444308785

[8] Bundschuh, J., Bhattacharya, P., Sracek, O., Mellano, M., Ramírez, A., Storniolo, A., Martín, R., Cortés, J., Litter, M. and Jean, J. (2011) Arsenic Removal from Groundwater of the Chaco-Pampean Plain (Argentina) Using Natural Geological Materials as Adsorbents. Journal of Environmental Science and Health Part A, 46, 1297-1310. http://dx.doi.org/10.1080/10934529.2011.598838

[9] Sarkar, S., Greenleaf, J.E., Gupta, A., Uy, D. and SenGupta, A.K. (2012) Sustainable Engineered Processes to Mitigate the Global Arsenic Crisis in Drinking Water: Challenges and Progress. Annual Review of Chemical and Biomolecular Engineering, 3, 497-517. http://dx.doi.org/10.1146/annurev-chembioeng-062011-081101

[10] Giles, D., Mohapatra, M., Issa, T., Anand, S. and Singh, P. (2011) Iron and Aluminium Based Adsorption Strategies for Removing Arsenic from Water. Journal of Environmental Management, 92, 3011-3022. http://dx.doi.org/10.1016/j.jenvman.2011.07.018

[11] Aredes, S., Klein, B. and Pawlik, M. (2012) The Removal of Arsenic from Water Using Natural Iron Oxide Minerals. Journal of Cleaner Production, 29-30, 208-213. http://dx.doi.org/10.1016/j.jclepro.2012.01.029

[12] Botto, I.L., González, M.J., Gazzolli, D. and Soto, E. (2013) Iron Activation of Natural Aluminosilicates to Remove Arsenic from Groundwater. Journal of Environmental Science and Engineering A, 2, 744-752.

[13] Dousova, B., Martaus, A., Kolousek, D., Fuitova, L., Machovic, V. and Grygar, T. (2009) Characterization of FeTrated Clays as Effective as Sorbents. In: Bundschuh, J., Armienta, M.A., Birkle, P., Bhattacharya, P., Matschullat, J. and Mukherjee, A.B., Eds., Natural Arsenic in Grounwater of Latin American. Arsenic in the Environment, Vol. 1, Taylor \& Francis Group, London, 511-520.

[14] O’Reilly, S.E., Strawn, D.G. and Sparks, D.L. (2001) Residence Time Effects on Arsenate Adsorption/Desorption Mechanisms on Goethite. Soil Science Society of America Journal, 65, 67-77. http://dx.doi.org/10.2136/sssaj2001.65167x

[15] Müller, K., Ciminelli, V., Dantas, M. and Willscher, S. (2010) A Comparative Study of As(III) and As(V) in Aqueous Solutions and Adsorbed on Iron Oxy-Hydroxides by Raman Spectroscopy. Water Research, 44, 5660-5672. http://dx.doi.org/10.1016/j.watres.2010.05.053

[16] Fernández-Turiel, J.L., Galindo, G., Parada, M.A., Gimeno, D., García-Vallés, M. and Saavedra, J. (2005) Estado actual del conocimiento sobre el arsénico en el agua de Argentina y Chile: Origen, movilidad y tratamiento. In: Galindo, G., Turiel, F., Parada, M. and Torrente, D., Eds., Arsénico en aguas: Origen, movilidad y tratamiento. IV Congreso Hidrogeológico Argentino, Río Cuarto, 25-28 October 2005, 1-22.

[17] Chen, R.Z., Zhang, Z.Y., Yang, Y.N., Lei, Z.F., Chen, N., Guo, X., Zhao, C. and Sugiura, N. (2011) Use of Ferric-Impregnated Volcanic Ash for Arsenate (V) Adsorption from Contaminated Water with Various Mineralization Degrees. Journal of Colloid and Interface Science, 353, 542-548. http://dx.doi.org/10.1016/j.jcis.2010.09.066

[18] Jaafarzadeh, N., Amiri, H. and Ahmadi, M. (2012) Factorial Experimental Design Application in Modification of Volcanic Ash as a Natural Adsorbent with Fenton Process for Arsenic Removal. Environmental Technology, 33, 159-165. 
http://dx.doi.org/10.1080/09593330.2011.554887

[19] SERNAGEOMIN (Servicio Nacional Geológico Minero, Chile) (2011) Reportes especiales de actividad volcánica complejo volcánico puyehue-Cordón Caulle. http://www.sernageomin.cl/volcan.php?iId=38

[20] Castro, J., Schipper, C., Mueller, S., Militzer, A., Amigo, A., Silva Parejas, C. and Jacob, D. (2013) Storage and Eruption of Near-Liquidus Rhyolite Magma at Cordón Caulle, Chile. Bulletin of Volcanology, 75, 1-17. http://dx.doi.org/10.1007/s00445-013-0702-9

[21] Botto, I.L., Canafoglia, M.E., Gazzoli, D. and González, M.J. (2013) Spectroscopic and Microscopic Characterization of Volcanic Ash from Puyehue-(Chile) Eruption: Preliminary Approach for the Application in the Arsenic Removal. Journal of Spectroscopy, 2013, Article ID: 254517. http://dx.doi.org/10.1155/2013/254517

[22] Daga, R., Ribeiro Guevara, S., Poiré, D. and Arribére, M. (2014) Characterization of Tephras Dispersed by the Recent Eruptions of Volcanoes Calbuco (1961), Chaitén (2008) and Cordón Caulle Complex (1960 and 2011), in Northern Patagonia. Journal of South American Earth Sciences, 49, 1-14. http://dx.doi.org/10.1016/j.jsames.2013.10.006

[23] Schwertmann, U. and Cornell, R. (2000) Iron Oxides in the Laboratory: Preparation and Characterization. 2nd Edition, WILEY-VCH, Weinheim. http://dx.doi.org/10.1002/9783527613229

[24] Celis, R., Cornejo, J. and Hermosin, M. (1998) Textural Properties of Synthetic Clay-Ferrihydrite Associations. Clay Minerals, 33, 395-407. http://dx.doi.org/10.1180/000985598545705

[25] Michel, F., Ehm, L., Antao, S., Lee, P., Chupas, P., Liu, G., Strongin, D., Schoonen, M., Phillips, B. and Parise, J. (2007) The Structure of Ferrihydrite, a Nanocrystalline Material. Science, 316, 1726-1729. http://dx.doi.org/10.1126/science.1142525

[26] Cornell, R. and Schwertmann, U. (2006) The Iron Oxides. Structure, Properties, Reactions, Occurrences and Uses. WILEY-VCH, Weinheim.

[27] Guo, H., Stüben, D. and Berner, Z. (2007) Removal of Arsenic from Aqueous Solution by Natural Siderite and Hematite. Applied Geochemistry, 22, 1039-1051. http://dx.doi.org/10.1016/j.apgeochem.2007.01.004

[28] Mamindy-Pajany, Y., Hurel, C., Marmier, N. and Roméo, M. (2009) Arsenic Adsorption onto Hematite and Goethite. Comptes Rendus Chimie, 12, 876-881. http://dx.doi.org/10.1016/j.crci.2008.10.012

[29] Tabelin, C., Igarashi, T., Moneda, T. and Tamamura, S. (2013) Utilization of Natural and Artificial Adsorbents in the Mitigation of Arsenic Leached from Hydrothermally Altered Rock. Engineering Geology, 156, 58-67. http://dx.doi.org/10.1016/j.enggeo.2013.02.001

[30] Amiri, H., Jaafarzadeh, N., Ahmadi, M. and Silva Martínez, S. (2011) Application of LECA Modified with Fenton in Arsenite and Arsenate Removal as an Adsorbent. Desalination, 272, 212-217. http://dx.doi.org/10.1016/j.desal.2011.01.018

[31] Haque, N., Morrison, G., Cano-Aguilera, I. and Gardea-Torresdey, J. (2008) Iron-Modified Light Expanded Clay Aggregates for the Removal of Arsenic(V) from Groundwater. Microchemical Journal, 88, 7-13. http://dx.doi.org/10.1016/j.microc.2007.08.004 